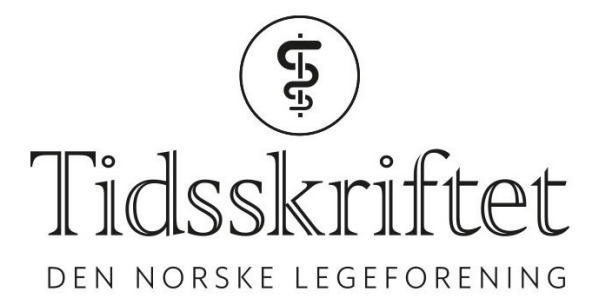

\title{
Forskning i studietiden må telle mer
}

LEDER

\section{BERIT SCHEI}

E-post: berit.schei@ntnu.no

Berit Schei (f. 1950) er spesialist i gynekologi og professor ved Institutt for samfunnsmedisin og sykepleie, Norges teknisk-naturvitenskapelige universitet. Hun er medlem av Legeforeningens forskningsutvalg.

Forfatter har fylt ut ICMJE-skjemaet og oppgir ingen interessekonflikter.

Den akademiske skoleringen er blitt en viktig del av legers grunnutdanning.

Da Øivind Larsen skrev om legeprofesjonens utvikling i anledning 10o-årsjubileet for Den norske legeforening, tok han for seg den manglende vitenskapelige skoleringen innen medisinstudiet: «Faktisk forutsetter mange medisinske karrieremønstre selvstendig kunnskapsproduksjon... Her er det en klar forskjell fra andre profesjoner - likevel er det medisinske studium $i$ Norge kjennetegnet av at det gis forsvinnende liten veiledning $i$ vitenskapelig arbeid» (1). Det har skjedd mye med utdanningen siden 1986 når det gjelder undervisning $\mathrm{i}$ vitenskapelige metoder og forskning. Blant annet har studentene fått muligheten til å forske selv. Omfanget og betydningen av et forskningsprosjekt varierer mellom studiestedene.

I dette nummer av Tidsskiftet presenteres en studie om hvilken betydning særoppgaven i legestudiet ved Universitetet i Bergen har for den videre karriere (2). Studien er basert på informasjon fra uteksaminerte medisinstudenter fra kullene 1996-98 som leverte særoppgave i perioden 2001-04. Av 397 leger fikk forfatterne kontakt med 253, hvorav om lag halvparten besvarte det utsendte spørreskjemaet. Resultatene tyder på at tema for særoppgaven kan ha betydning for valg av spesialitet. Når det gjelder særoppgavens betydning for videre forskning, fant forfatterne at $19 \%$ hadde fått publisert sine resultater. Publisering ga økt sannsynlighet for at studenten fortsatte forskningskarrieren med en ph.d-grad.

Da det medisinske fakultet ved Norges teknisk-naturvitenskapelige universitet tok opp studenter til et fullt medisinstudium i 1993, var det allerede satt på studieplanen at alle skulle utføre et stykke vitenskapelig arbeid. Det ble innført et eget semester der den formelle undervisningen bare var knyttet til forskningsoppgaven. Som ledd i en pågående revisjon av hele medisinstudiet i Trondheim ble det i 2016 foretatt en gjennomgang av undervisningen innen forskningsmetode (3). Her pekes det på at den undervisningen studentene får knyttet til gjennomføring av hovedoppgaven, er like omfattende som en mastergrad og viktig for den totale heving av kompetansen innen forskningsmetode.

I 2012 leverte en medisinstudent i Trondheim en hovedoppgave om nettopp hovedoppgaven på medisinstudiet (4). Et spørreskjema ble sendt til medisinstudentene i byen som fullførte utdanningen i perioden 2002-1. Av dem som svarte på undersøkelsen 
(451 leger; svarandel 74\%), hadde $29 \%$ fått arbeidet sitt publisert i etterkant av hovedoppgaven.

Disse to studiene er ikke grunnlag godt nok til å fastslå at flere får publisert arbeidet sitt $\mathrm{i}$ Trondheim enn i Bergen. Men det er vel ikke usannsynlig at jo større omfang hovedoppgaven har, desto mer tid og krefter blir lagt inn i arbeidet, både fra studentens og veilederens side, noe som $\emptyset$ ker sjansen for at arbeidet blir publisert. I den sammenheng er det relevant at særoppgaven i Bergen har et omfang tilsvarende 15 studiepoeng, mens hovedoppgaven som Trondheims-studentene leverer, tilsvarer 30 studiepoeng.

Samtidig med den positive utviklingen hva gjelder akademisk skolering i legers grunnutdanning har det skjedd en total omlegging av den videre akademiske utdanningen. Med kvalitetsreformen i 2002 ble dr.med. erstattet med ph.d.-graden (5). Dette førte til en stor $ø$ kning i antall avlagte doktorgrader, for eksempel har antallet ved Det medisinske fakultet ved Norges teknisk-naturvitenskapelige universitet ifølge interne opptellinger $ø \mathrm{kt}$ fra åtte i 1997 til 8 o i 2016. Men det er andre enn leger som utgjør hoveddelen av økningen.

Dagens ph.d.-grad består kun av tre års arbeid, hvorav et halvt år er avsatt til opplæring. For en student som har gått gjennom kvalitetsreformens faste utdanningsstruktur - tre år for bachelorgraden og ytterligere to års studier for å oppnå mastergrad - kan den høyeste formelle vitenskapelige «eksamen» i form av ph.d.-graden oppnås etter kun åtte år, litt mer enn lengden på et legestudium. Legestudiet passer ikke inn i kvalitetsreformens struktur og er unntatt fra denne når det gjelder grunnutdanningen. I mange deler av verden, for eksempel i Canada, USA og Storbritannia, møtes man i medisinske forskningsmiljøer med: «Hvorfor har norske leger ph.d. når dere allerede er MD?» Kanskje dagens ph.d.-grad heller ikke passer inn i det vitenskapelige karriereløpet for leger?

Egen forskerlinje for medisinstudenter ble opprettet i 2002. Den krever ett års ekstra studium. For å få godkjent forskningsåret må det leveres en forskerlinjeoppgave som består av et selvstendig sammendrag, som i en ph.d.-grad, og 1-2 artikler. Med dagens ordning får om lag $10 \%$ av medisinstudentene dette tilbudet. Disse må tillegg til forskningsåret også levere den obligatoriske hovedoppgaven. Kanskje kunne de to vitenskapelige løpene med henholdsvis hovedoppgave (med omfang svarende til zo studiepoeng) og forskerlinjekompetanse samordnes - slik at mange flere kan få en formell vitenskapelig kompetanse som del av medisinsk embetseksamen?

I Legeforeningen forskningspolitiske strategi, Forskning for en bedre helse (6), påpekes det at forskning må være et attraktivt karriereløp for leger og forskning ikke bør innebære $\emptyset$ konomisk tap. Nå som økt formalisering av vitenskapelig kompetanse innen grunnutdanningen og spesialistutdanningen er i støpeskjeen, kan det være anledning til å tenke nytt.

\section{LITTERATUR:}

1. Larsen $\emptyset$, Berg O, Hodne F. Legene og samfunnet. Oslo: Seksjon for medisinsk historie, Universitetet i Oslo, 1986: 484 .

2. Kolstad E, Salomon-Johannessen EE, Owe J et al. Har særoppgaven i legestudiet betydning for videre karrierevalg? Tidsskr Nor Legeforen 2017; 137:1021 - 5 .

3. Vitenskapelig kompetanse. Rapport. Trondheim: Det medisinske fakultet, Norges teknisknaturvitenskapelige universitet, 2016.

4. Rosland MO. Has the student's theses influence on later medical career? Doktoravhandling. Trondheim: Det medisinske fakultet, Norges teknisk-naturvitenskapelige universitet, 2012.

5. Gjersvik PJ. PhD skal erstatte dr.med. Tidsskr Nor Lægeforen 2002; 122: 1065.

6. Forskning for en bedre helse. Legeforeningens forskningspolitiske strategi 2017-2020. Oslo: Den norske legeforening, 2017. 
Publisert: 21. august 2017. Tidsskr Nor Legeforen. DOI: 10.4045/tidsskr.17.0653 (c) Tidsskrift for Den norske legeforening 2020. Lastet ned fra tidsskriftet.no 